\title{
RADIKALISASI DAN MODERASI : STUDI GERAKAN ISLAM MAINSTREM JAMA’AH ISLAMIYAH DAN NAHDATUL ULAMA DI INDONESIA
}

\author{
Abdurrasyid \\ Universitas Islam Negeri Raden Fatah Palembang \\ abdurrasyidust@gmail.com
}

\begin{abstract}
Abstrak
Tulisan ini akan mengurai dan menjelaskan gerakan moderasi yang digagas dan digerakkan oleh organisasi Islam Nahdhatul Ulama dan gerakan radikal yang dilakukan oleh Jama'ah Islamiyah. Fokus tulisan ini akan melihat bagaimana gagasan dan pandangan dua organisasi islam tersebut (NU dan JI) terhadap relasi agama dan politik. Penelitian ini menggunakan metode kualitatif dengan analisa dekriptif, sumber data yang digunakan adalah pengamatan di lapangan dan didukung dengan literatur-literatur terkait tema. Gerakan moderasi NU merupakan manifestasi dari ideologi yang terbentuk dalam rentang sejarah yang sangat panjang yang dipengaruhi oleh banyak hal, salah satu yang paling penting adalah budaya. Kontekstualisasi dan internalisasi atas tafsir serta interpretasi terhadap teks-teks suci yaitu Al qur'an dan Hadits, melahirkan konsep-konsep seperti pluralisme dan toleransi. Pembumian ajaran Islam sesuai dengan konsep rahmatan lil alamin yang ada dalam Al- Qur'an sehingga tidak menjadikan organisasi ini menjadi ekstrim kiri atau pun kanan (moderat). Islam hadir sebagai suatu agama yang meletakan hubungan politik dan Islam sebagai dua sisi saling melengkapi dan menjaga identitasnya masing-masing. Islam memerlukan politik dan negara untuk media menumbuhkembangkan ajarannya disegala aspek kehidupan masyarakat, sementara negara membutuhkan Islam untuk menjaga, memelihara dan membimbing kehidupan bernegara dan bermasyarakat. Disisi lain, Jama'ah Islamiyah yang dikenal dengan kelompok ekstremis yang menginginkan sebuah tatanan sistem kenegaraan yang bernama "al-Khilafah al-Islamiyah", segala cara dan upaya harus dilaksanakan demi tegaknya negara Islam termasuk jalan perang (jihad) dengan kekerasan, hal ini merupakan manifestasi dari ideologi penerapan syari'at Islam secara kaffah dan syumul.
\end{abstract}

Kata Kunci :

Nahdhatul Ulama;Moderasi; Jama'ah Islamiy; Radikalisme.

\begin{abstract}
This paper will parse and explain the moderation movement initiated and mobilized by the Islamic organization Nahdhatul Ulama and radical movements conducted by Jama'ah Islamiyah. The focus of this paper will look at the Islamic philosophy and vision (NU and JI) on religious and political relations. This research uses qualitative method with descriptive analysis, that is data used in research and supported by theme-related literatures. The NU moderation movement is a manifestation of ideology formed in many spaces, one of the most important being culture. Contextualization and internalization of the interpretation of the sacred texts namely Al Quran and Hadith, birth concepts such as pluralism and endurance. The earthing of Islamic teachings in accordance with the concept of rahmatan lil alamin existing in the Qur'an can not be a left or right object (moderate). Islam is present as a religion that lays political and Islamic relations as two sides complement each other and maintain their own identity. Islam requires politics and state for the media to develop its teachings in all aspects of community life, while the state needs Islam to safeguard, guard and guide the life of the state and society. On the other hand, Jama'ah Islamiyah known as extremist groups who want a system of state order called "al-Khilafah al-Islamiyah", various ways and efforts must be implemented for the sake of the establishment of an Islamic state including the path of war (jihad) with violence, manifestation of the ideology of the application of Islamic Shari'ah in kaffah and syumul
\end{abstract}

Keywords:

Nahdhatul Ulama;Moderasi; Jama'ah Islamiy; Radikalisme 


\section{PENDAHULUAN}

Perkembangan Islam dalam rentang sejarah melahirkan politik dan agama yang berhilir pada munculnya gerakan Islam politik yang saling berhadaphadapan. Satu sisi Islam yang melakukan tindakan radikal sementara sisi lain Islam yang bertindak secara moderasi (jalan tengah).

Dari sudut gerakan Islam mainstrem yang berhaluan radikal selalu menunjukan beberapa aktivitas terorism. Ini dapat dilihat dari aksi perlawanan dengan taktik konfrontasi dengan kekerasan dan obyek atau sasaran aksi tersebut seperti aksi pengeboman di rumah ibadah, hotel dan fasilitas umum lainnya bahkan daerah yang menjadi sasaran praktis gerakan tersebut. Pada dekade 1999 s/d 2009 menegaskan bahwa Indonesia tempat "subur" bagi perkembangan ideologi Islam garis keras. Uniknya kelompok Islam yang menggunakan perlawanan dengan cara "terorisme" tersebut hadir di tengah masyarakat Indonesia pasca runtuhnya Orde Baru dengan sistem politik represifnya.

Ada ruang yang selama masa Orde Baru dapat "dikendalikan" tetapi pada masa Reformasi ruang tersebut menjadi sesak dengan kekerasan terorisme yang dilakukan oleh kelompok Islam garis keras seperti Jema'ah Islamiyah, Majlis Mujahidin Islamiyah, Al Qaedah, Jamaah Anshari At-Tauhid dan yang terkini Jamaah Anshar Ad-daulah. Apa yang dilakukan kelompok-kelompok Islam garis keras ini tidak sekedar penegakan Khilafah raya tetapi bagian realitas konflik struktural perebutan wilayah kekuasaan yang bersumber dari kepentingan ekonomi, pembangunan dan formasi sosial berideologi keagamaan.

Di sisi Islam mainstream lainya adalah Islam yang moderasi yakni: Islam hadir sebagai suatu agama yang meletakan hubungan politik dan Islam sebagai dua sisi saling melengkapi dan menjaga identitasnya masing-masing. Islam memerlukan politik negara untuk media menumbuhkembangkan ajarannya disegala aspek kehidupan masyarakat, sementara negara membutuhkan Islam untuk menjaga, memelihara dan membimbing kehidupan bernegara dan bermasyarakat. Kenyataan ini paling tidak disebabkan karena Islam mempunyai dua tradisi yang saling melengkapi, terus dipertahankan dan dikembangkan, serta selalu diperbarui, yang mengikat tampilan universal dan kosmoplitan baik lokal dan nasional. Seperti Nahdhatul Ulama dan Muhammadiyah.

Kedua organisasi ini memiliki pemikiran yang mengetengahkan bahwa Islam dan politik berdiri secara terpisah namun saling melengkapi artinya Islam mesti diterapkan sebagai etika dan moral sosial, bukan hukum positif yang melekat pada negara. Islam harus melindungi wawasan nasional, bukan wawasan keagamaan eksklusif. Islam sebagai agama mayoritas sebagai satu komponen penting dari struktur sosial Indonesia, Islam tidak boleh menempatkan dirinya dalam posisi yang bersaing vis a vis komponen-komponen lainnya. Islam

Berdasarkan pemikiran di atas, penelitian ini akan melihat Islam dalam aktivitas gerakan radikal yang dilakukan oleh Jamaah Islamiyah Indonesia dan Islam moderasi dalam aktivitas yang dilakukan oleh gerakan Nahdhatul Ulama. Selain itu, penelitian ini juga akan menggambarkan akar pemikiran yang menjadi dasar ideologis masing-masing gerakan, baik yang terkait dengan kesejarahan,maupun dengan perubahan sosial. 
Seturut dengan pemikiran di atas, pokok pikiran penelitian ini adalah akar ideologis dari Islam radikal dan Islam moderasi di Indonesia. Pokok pikiran ini akan menggarisbawahi akar ideologis Islam dari Jama'ah Islamiyah dan Nahdhatul Ulama di Indonesia dan bentuk-bentuk tindakan radikal dari gerakan Jama'ah Islamiyah dan apa bentuk-bentuk tindakan moderasi dari Nahdhatul Ulama di Indonesia.

Perbedaan dengan penelitian ini adalah pada fokus penelitian yakni proses pembentukan struktur radikalisme pada Jama'ah Islamiyah dan struktur moderasi pada Nahdhatul Ulama di Indonesia.

\section{HASIL DAN PEMBAHASAN}

\section{Orientasi ideologi dalam gerakan islam indonesia}

Berbagai gerakan umat Islam yang menandai kebangkitan Islam di perempat pertama adab ke-20 mulai muncul setelah kebangkitan elite baru di kalangan umat Islam Indonesia yang tidakhanya memperoleh pendidikan dari lembaga pendidikan agama tradisional maupun lembaga pendidikan sekuler, tetapi juga memperoleh ide-ide dari luar, dari gerakan nasionalis di berbagai negeri jajahan,atau dari gerakan kebangkitan di dunia Islam. Namun, perbedaan latar belakang pendidikan elite umat lslam Indonesia menimbulkan perbedaan orientasi ideologis.

Gerakan keagamaan umat Islam yang dipimpin oleh para ulama muncul sebagai gerakan yang di maksudkan untuk memajukan atau mempertahankan mazhab keagamaan tertentu. Dari perspektif ini, gerakan keagamaan umat Islam Indonesia bisa dibedakan menjadi dua jenis. Pertama, gerakan keagamaan yang berusaha memajukan ortodoksi salafiyah, yang mengajak umat Islam kembali kepada praktik keagamaan di masa Nabi dan para Sahabatnya ketika aliran-aliran (mazhab-mazhab) pemahaman belum ada. Kedua, gerakan keagamaan yangtetap mempertahankan tradisionalisme mazhabiyah, yang menganjurkan umat Islam untuk tetap mengikuti mazhab-mazhab keagamaan yang menjadi anutan dan amalan mayoritas umat Islam, terutama empat mazhab yang telah mapan selama berabad-abad. Di samping itu, gerakan politik umat Islam yang dipimpin oleh intelektual. Muslim muncul sebagai kelanjutan perjuangan untuk membebaskan rakyat Indonesia dari penjajahan asing dan pada saat yang sama juga dari feodaiisme pribumi.

\section{Gerakan Organisasi Islam : Fakta Kekerasan Atas Nama Agama}

Apabila menilik lebih jauh ke masa lalu, dari manusia pertama dilahirkan semenjak itu pula kekerasan muncul, kekerasan muncul seiring dengan perkembangan umat manusia. Kekerasan masuk ke dalam tubuh manusia, tubuh yang di ciptakan oleh sang kuasa untuk tugas yang mulia sebagai khalifah di muka bumi, perlahan digunakan untuk berbuat sesuatu yang "keras", tangan perlahan digenggam untuk memukul manusia lain, kaki perlahan diayunkan untuk menendang manusia lainnya, mulut perlahan sesumbar untuk mencaci manusia lainnya.

Pembicaraan tentang radikalisme tidak bisa kita lepaskan dari sejarah perkembangan umat manusia itu sendiri, ketika manusia telah membentuk suatu 
komunitas (kelompok), maka tidak bisa kita hindarkan lagi dalam kelompok tersebut akan timbul suatu pembacaan yang berbeda muncul dari individuindividu dan itupun bisa berimbas ke arah yang radikal. Sejarah panjang radikalisme dalam perkembangan umat manusia bisa kita lihat dalam fenomenafenomena yang telah terjadi pada masyrakat-masyarakat dan kelompok-kelompok sebelum kita, pada abad ke 1 yang terjadi di arab dimana pengikut ali bin abi thalib yang membelot yang kita kenal dengan peristiwa arbitrase, di india fenomena radikalisme bisa kita lihat ketika terjadinya respon ketika imperior moghul menaklukan India dan di iringi penjajahan Inggris yang di dalamnya juga terdapat agenda-agenda misionaris dalam rangaka meng"konversi" hindu ke kristen sehingga akibat dari itu timbul sebuah gerakan untuk mencounter hal tersebut yang dipelopori oleh Svami Dayananda Saravasti dengan kelompoknya yang kita kenal dengan Arya Sumaj (himpunan kaum mulia), selain itu ada juga tokoh yang keras dalam hal pemikiran dan halus dalam tindakan dalam menggerakkan suatu tujuan yaitu Mahatma Gandhi.

Berbicara masalah gerakan radikal, mau tidak mau kita harus mengaitkannya dengan ideologi. Para pelaku terorisme atau gerakan radikal dapat dipastikan terjadi atas dorongan sebuah ideologi. Tidak mungkin manusia akan bertindak sedemikian bodoh, jika dia tidak dipengaruhi kekuatan ideologi. Karena, sebagaimana kata Karl Marx, ideologi telah memalsukan kesadaran manusia, sehingga sebab ideologi manusia pun bisa melakukan segala sesuatu dengan tanpa keberatan sedikitpun.

Secara bahasa radikalisme bisa diartikan sebagai suatu faham atau aliran yang menginginkan perubahan atau pembaharuan dalam bidang sosial atau politik dengan cara kekerasan, ekstrim, dan drastis. Dalam ensiklopedi indonesia dijelaskan bahwa radikalisme adalah semua aliran politik, yang para penganutnya menghendaki konsekuensi yang ekstrim, setidak tidaknya konsekuensi yang paling jauh dari pengejawantahan yang mereka anut (ihktiar baru -van hoeve,cet 1984). Sedangkan dalam kamus ilmiah populer karangan Pius A partanto dan m dahlan radikalisme diartikan sebagai faham politik kenegaraan yang menghendaki adanya perubahan dan perombakan besar sebagai jalan untuk mencapai taraf kemajuan, dari beberapa definisi di atas kita dapat mengambil beberapa poin penting bahwa radikalisme merupakan suatu gerakan yang proses pencapaian misinya menggunakan cara-cara yang ekstrim dan bahkan dengan cara kekerasan.

maraknya aksi terorisme yang mengatasnamakan wahyu agama, dan fenomena perbedaan pendapat dalam beragama yang mengakibatkan kekerasan adalah fenomena yang sagat memilukan, karena akibat dari itu semua sangat menguncang keadaan soial masyrakat indonesia, seperti yang telah dicontohkan di atas fenomena penyerangan kelompok ahmadiyah di jawa barat dan kelompok syi'ah di sampang madura merupakan fakta yan tidak bisa dibantah, bahwa dalam pembacaan terhadap ajaran agama sering kali terjadi kesalahfahaman yang ujungujungnya akan menyebabkan tindakan kekerasan.

Gejala kekerasan menjadi Pelik karena selain gejala yang tampak di permukaan, tidak tahu persis diluar fakta yang sebenarnya, apakah terorisme itu mengandung muatan kepentingan politik atau tidak seperti beberapa spekulasi 
yang berkembang dewasa ini. ${ }^{1}$ Kekerasan agama bahkan menjadi paradoks ketika dikaitkan dengan agama yang pada dasarnya semua agama mengajarkan nilai-nilai perdamaian, kebaikan, penylamatan, dan ketentraman hidup.Terlebih Islam yang secara harfiah bermakna damai, selamat, dan pasrah. Islam bahkan mengemban misi rahmatan lil'alamin di muka bumi. Nabi dan kaum muslimin generasi awal bahkan menampilkan peradaban Islam yang menjadi pencerah bagi kehidupan semesta. Inilah agama hanif yang tampil sebagai agama peradaban sehingga di kemudian hari meluas ke seluruh penjuru bumi.

Di tubuh umat Islam Indonesia, setelah reformasi tahun 1998 kehadiran kelompok-kelompok keagamaan yang cenderung "true believers" dan rawan memicu kekerasan tampaknya mendapatkan dorongan yang semakin kuat dan sekaligus terbuka dengan hadirnya kembali " kebangkitan" Islam dalam bentuk neo revivalisme Islam, yang melahirkan corak Islam ideologis yang militan. ${ }^{2}$ Islam dipertautkan dengan dua kepentingan yang berhimpitan, yaitu gerakan pemurnian yang bersifat kaku dan keras bersenyawa dengan Islam yang ingin membangun sistem Islam (an-nizam al-Islami) dalam negara (Islamiyyah) atau menghimpitkan dakwah Islam dan politik. Kecenderungan yang baru ini melahirkan gerakan Islam dan ideologi politik Islam yang militan. Islam ini memang membawa nilai baru, yaitu "politik-isme": politik (kekuasaan) sebagai cara dan tujuan dakwah Islam. Hanya melalui jalur politik, Islam bisa berjaya, menandingi hegemoni Barat yang menurut mereka begitu pogah.Melalui politik pula, hukum Allah dapat ditegakkan, dan membatalkan hukum-hukum skular, produk dari zaman yang mereka sebut "jahiliah modern". 3

George Junus Aditjondro dalam salah satu tulisannya menyatakan bahwa fenomena kekerasan agama yang terjadi mengatakatan bahwa antara agama yang dianut pelaku dan korban tidak berdiri sendiri akan tetapi ada hal lain yang berdiri disana $^{4}$, kasus yang terjadi di medan antara HKBP di medan dan penganut agama formalim, walaupun mereka sama-sama batak toba akan tetapi mereka lahir dari kelas sosial yang berbeda, para jemaah yang menolak pendirian rumah ibadah para penganut foemalim berasal dari kelas menengah ke atas sebaliknya mereka yang jadi korban adalah masyarakat dari golongan menengah ke bawah, begitu juga dengan konflik yang ada di poso umat Islam di sana lahir dari kelas-kelas menengah ke bawah yang mata pencaharian meraka adalah nelayan, buruh pelabuhan, dan mereka juga notabenenya adalah pendatang yang banyak datang dari gorontalo, sulawesi selatan dan jawa. sedangkan umat kristiani mereka adalah orang-orang asli pribumi dari suku pamona, mori dan lore, serta migran dari toraja, yang sebagian mereka mata pencahariannya sebagai pegawai negeri, pegawai gereja, dan mereka bisa dianggap kaum dengan kelas menengah ke atas, dari fakta-fakta yang terjadi di atas walaupun yang muncul ke permukaan adalah

\footnotetext{
${ }^{1}$ Haedar Nashr, "Ormas Islam dan Kekerasan Atas Nama Agama” dalam makalah yang disampaikan pada Sarasehan Tokoh Umat Islam Yogyakarta, Rabu 25 Mei 2011.

${ }^{2}$ Ibid.

${ }^{3}$ Syaiful Arif, Deradikalisasi Islam: Paradigma dan Strategi Islam Kultural, (Koekoesan: Jakarta, 2010), halaman. 2.

${ }^{4}$ George Junus Aditjonro, Agama Bukan Akar Kekerasan Massa, Dlm Indoprogress Agama Dan Negara, Yogyakarta, Resist Book, 2011.
} 
kekerasan atas nama agama akan tetapi dibalakngnya ada hal lain yang berdiri yaitu kelas sosial dan etnisitas.

\section{Nahdhatul Ulama dan Jama'ah Islamyah trajektori Pemikiran Dan Gerakan}

Nahdhatul Ulama (NU) merupakan salah satu organisasi terbesar di Indonesia, sebagai sebuah organisasi NU mempunyai peranan yang sangat besar dalam pembentukan karakter bangsa di Indonesia, sejak didirikan pada tahun 1926, nu sebagai sebuah organisasi tidak hanya berkutat dalam masalah keagamaan ansikh, lebih dari itu nu turut beperan aktif dalam menghadapi persoalan-persoalan social-masyarakat, ekonomi, dan politik.

Wahab Hasbullah muda salah satu pendiri NU, telah menggagas sebuah pergerakan yang bernama tashwirul afkar atau pertukaran pemikiran. Tujuan penting dari gerakan ini adalah untuk membuka dan memperluas cakrawala atau khazanah kaum pesantrenyang sesuai dengan falsafah al muhafadzah ala al qadim al shalih wa al akhdu bi al jaded al ashlah.

Nahdhatul ulama di awal pendiriannya berusaha untuk menjawab dua tantangan global di masa itu, yang pertama adalah globalisasi wahabi, dimana pada waktu itu arab Saudi dikuasai oleh kelompok wahabi dan dunia Islam banyak mengimpor gagasan wahabi dalam bnetuk pemurnian Islam, dan yang kedua adalah salafiyah dengan cara masing-masing ; globalisasi imperilaisme fisik yang dilakukan oleh belanda, inggris dan jepang. Untuk mnjawab tantangantantangan inilah didirikanlah sebuah organisasi yang bernama nahdhatul ulama. Dari lintas sejarah berdirinya Nahdhatul Ulama maka muncullah tiga pilar penting dalam organisasi NU yaitu: (1) Wawasan Ekonomi kerakyatan, (2) Wawasan Keilmuan, Sosial Budaya, dan (3) Wawasan Kebangsaan. ${ }^{5}$

Secara garis besar pokok perjuangan atau orientasi gerakan NU di bidang sosial kemasyarakatan dapat dibagi menjadi dua fase yaitu fase sebelum dan sesudah munculnya Gerakan kembali ke khittah 1926 pada Muktamar NU Situbondo 1984. Termasuk di bidang sosial-kemasyarakatan, menurut A. Sunarto A.S. ada dua alasan pokok yang dikemukakan oleh Gusdur terkait pribumisasi Islam.Pertama, alasan historis bahwa pribumisasi Islam merupakan bagian dari sejarah Islam. Baik di negeri asalnya maupun negeri lain termasuk Indonesia. Kedua, proses pribumisasi Islam berkaitan erat antara fikih dengan adat. Menurutnya, adat tidak mengubah nash, melainkan hanya mengubah atau mengembangkan implementasinya agar lebih fleksibel. ${ }^{6}$

Menurut KH. Ahmad Mustofa Bisri, setidaknya ada 3 jenis politik dalam pemahaman Nahdlatul Ulama, yaitu politik kebangsaan, politik kerakyatan dan politik kekuasaan. Nahdlatul Ulama sejak berdiri memang melakukan aktivitas politik, terutama dalam pengertian yang pertama, yakni politik kebangsaan, karena Nahdlatul Ulama sangat berkepentingan dengankeutuhan Negara Kesatuan Republik Indonesia (NKRI). Peta politik NU kemudian dilanjutkan dengan berubahnya NU menjadi partai politik di tahun 1955 setelah sebelumnya bergabung dengan Masyumi bersama organisasi Islam lainnya. Pada masa

${ }^{5}$ Achmad Hasyim Muzadi dkk, Profil dan DIrektori Nahlatul Ulama dari masa ke masa (Jakarta: PT.Yellow Multi Media, 2009) hlm. 34-35.

${ }^{6}$ A. Sunarto AS 
Demokrasi Terpimpin NU dikenal sebagai partai yang mendukung Sukarno, dan bergabung dalam NASAKOM (Nasionalis, Agama, Komunis) Nasionalis diwakili Partai Nasional Indonesia (PNI) Agama Partai Nahdhatul Ulama dan Partai Komunis Indonesia (PKI). Setelah itu NU maju ke panggung politik praktis bersama Partai Persatuan Pembangunan (PPP).

Penerimaan ungkapan tajdid dalam wacana keagamaan di kalangan ulama NU adalah suatu fenomena yang sangat menarik yang mungkin tak terbayangkan sebelumnya.Begitu fenomenal karena ternyata tiga tokoh ulama, K.H. Ali Ma'sum (1915-1989), K.H. Ahmad Siddiq (1926- 1991), dan K.H. Ali yafie (1. 1991), melangkah lebih jauh paling tidak secara intelektual.Dalam khotbah iftitah pada Musyawarah Nasional Alim Ulama NU dan Konf'erensi Besar NU di Cilacap tahun 1987, K.H. Ali Ma'sum menyinggung masalah tajdid. Kata beliau:

Kita tidak menolak adanya kemungkinan tajdid dan munculnya mujadid di Indonesia asal benar-benar sesuai dengan tuntutan. Memang kemungkinan itu telah dijanjikan oleh Nabi kita sendiri bahwa disetiap 100 tahun, umat lslam akan kedatangan mujadid.... Maka kami mengharapkan Munas dapat merumuskan hakikat tajdid itu. ... Karena sepengetahuan kami, tajdid itu tidak lain adalah 'menghidupkan sesuatu dan mengembalikannya kepada yang asli. $^{7}$

Bersebarangan dengan gerakan Nahdhatul 'Ulama, Jamaah Islamiyah menjadi representasi dari sebuah kelompok Islam yang beroperasi secara rahasia dan organisasi militan Islam di Asia Tenggara yang berupaya mendirikan sebuah negara Islam raksasa di wilayah negara-negara Indonesia, Singapura, Brunei, Malaysia, Thailand dan Filipina. Pemerintah Amerika Serikat menganggap organisasi ini sebagai organisasi teroris, sementara di Indonesia organisasi ini telah dinyatakan sebagai "korporasi terlarang".

Jemaah Islamiyah dicurigai melakukan aksi pengeboman Bali 2002 pada tanggal 12 Oktober 2002.Dalam serangan ini, pelaku bom bunuh diri dari Jemaah Islamiyah disebut-sebut menewaskan 202 orang melukai beberapa lainya di sebuah nightclub.Setelah serangan ini, Departemen Luar Negeri Amerika Serikat menyatakan Jemaah Islamiyah sebagai pelakunya dan menyatakannya sebagai Organisasi TerorisAsing. Jemaah Islamiyah juga dicurigai melakukan pengeboman Zamboanga, pemboman Metro Manila, dan pemboman kedutaan Australia 2004 di Jakarta. Bahkan dinyatakan bahwa Jamaah Islamiyah pertama kali melibatkan dirinya sebagai kelompok sel teror yang menyediakan dukungan keuangan dan logistik bagi operasi Al-Qaida di Asia Tenggara.

Organisasi Jemaah Islamiyah berada di Indonesia di sekitar tahun 1969, tokoh dan sekaligus pemimpinnya untuk pertama kali adalah Abdullah sungkar.Misi pertama organisasi ini di Indonesia adalah melakukan operasi untuk mengembangkan Darul Islam, sebuah kelompok konservatif Islam.

${ }^{7}$ Lihat keputusan Munas alim Ulama NU dan Konferensi Besar NU di Cilacap, 15-18 November 1987 di pesantren Ihya Ulumuddin, Kesuguhan, Cilacap, Jawah Tengah, Penerbit AlAlawiyah, Semarang. 
Serangan teroris Jamaah Islamiyah akan terus dilancarkan hingga negara Islarn berdiri di Indonesia.Organisasi garis keras itu bahkan berencana menjadikan Indonesia sebagai ibu negara Daulah Islamiyah Nusantara di wilayah Asia Tenggara. Sebagai catatan bahwa Abdullah Sungkar dan Abu Bakar Ba'asyir, keduanya aktivis Al-Irsyad dan DDII, yang bergabung dengan DI pada 7976. Pada 1 Januari 1993, Abdullah sungkar dan para pengikutnya memutuskan keruar dari DI dan rnembentuk Jamaah Islamiyah. Inilah gerakan Islam pertama di Indonesia yang secara terang-terangan menganut faham Salafy Jihadisme.Belakangan para aktivisnya banyak yang terlibat berbagai kasus terorisme di Indonesia. Keterkaitan antara DII dengan JI adalah keterkaitan ajaran semata yakni Abdullah sungkar menganut paham salafy jihadisme. Tokoh utama organisasi Jama'ah Islamiyah Indonesia berdasarkan penelusuran berapa data yakni; Abdullah Sungkar, Ridwan Isamudin, dan Abdul Azizz. ${ }^{8}$

Analisa lain datang dari Rohan Gunaratna' Penulis buku Inside al-qaida: Global Network of Terror. ${ }^{9}$ Ia mengatakan, Jemaah Islamiyah merupakan organisasi satelit al-Qaida. Jemaah Islamiyah merupakan sebuah organisasi militer yang muncul pada 1988 di Asia Tenggara.Antar keduanya terjadi peleburan secara efektif melalui bentuk kepemimpinan.aksi, dan pendanaan. Menurutnya, al-Qaida merembes masuk melalui organisasi rniiitan di dua tempat Kumpulan Mujahidin Malaysia di Malaysia dan Majelis Mujahidin di Indonesia.

Tujuan mereka antara lain mendirikan Khilafah lslam yang terbentang antara Thailand selatan, Singapura' Malaysia' Indonesia, Kamboja hingga Filipina selatan. Baik Abdullah Sungkar maupun Abu Bakar Ba'asyir adalah dua sosok di balik organisasi tersebut' Jernaah Islamiyah digagas Abdullah Sungkar di Malaysia pada 1994. Jamaah Islamiyah (JI) dalam Resolusi PBB 1390/2002 dituding sebagai organisasi teroris bersama 25 organisasi teroris lainnya, terutama di dunia Islam JI dianggap sebagai kepanjangan tangan Al-Qaeda di Asia Tenggara, Bukti keberadaan JI didapat dari Dokumen PUPJI (Pedoman Umum Perjuangan Jama'ah Islamiyah). Dokumen PUPJI yang terdiri atas 15 bab dan 43 pasal tersebut, diterbitkan di Malaysia oleh Majlis Qiyadah Markaziyah AlJamaah Al-Islamiyah ( Kantor Pusat JI ) pada 30 Mei 1996.

Beberapa surat kabar dan media memuat berita tentang bukti keberadaan Jama'ah Islamiyah dan aktivitas jihadnya ditemukan di Desa Sayangan Solo. Barang bukti yang ditemukan di rumah berukuran 3x3,5 meter itu adalah bukubuku benjudul: Pedoman Umum Perjuangan Jamaah Islamiyah, Pembentukan Sikap Dasar Jamaah lslamiyah, Laporan PTA Yamuq Dauru I, Cara Membuat Bom, Islarnic military of Jemaah Islamiyah 16 buku ke militeran, peta dan topografi gambar-gambar senjata api ukuran kertas Koran.

Abdullah Sungkar dan Abu Bakar Ba'asyir, serta Thoriqudin alias Hamzah dan Iain-lain adalah pendiri Jama'ah Islamiyah yang bertujuan iqomatudien(menegakkan syari'at Islam) lewat jalan jihad fisabilillah. Berbagai maroji atau buku-buku rujukan yang berkaitan dengan jama'ah dikaji dan

${ }^{8}$ Tempo, 14 Januaru 2001, 15 Februari 2007, ZO Oktober 2001,Agustus 2003, Koran Kompas, 22,28,26 Agastus 2009

${ }^{9}$ Kompas, 26, Agustus 2009 
didiskusikan.Ada tiga buku penting yang menjadi rujukan. Pertama, At Thoriq ilajama'atil Muslimin(Menuju Jamiatul Muslimin) karya Hussain bin Muhammad bin Ali Jabri. Kedua, Al Manhaj Al Haraki Li Sirah An Nabawiyah (Manhaj Haraki atau Metode Pergerakan Menurut Sejarah Perjuangan Nabi) karya Syaikh Munir Muhammad Al Ghadhban.Terakhir, Mitsaq Amal Al Islami (Pedoman Amal Islam)karya Najih Ibrahlm, Ashlm Abdul Majid, Ishamudin Darbalah. ${ }^{10}$

Dalam penyingkapan beberapa gerakan subversive tahun 1970-an hingga awal 1980-an, yang antara lain melibatkan gerakan Komando Jihad (Komji), Teror Warman, maupun Jamaah Imran, nama Jamaah Islamiyah belum disebutsebut didalamnya. Baru pada pertengahan tahun 1980-an nama Jamaah Islamiyah muncul dalam beberapa persidangan khusus subvertif komando jihad, teror Warman dan Usroh. Ketika itu Jamaah Islamiyah sering disebut secara bergantian dengan istilah lain yaitu "Kelompok Teror Warman", dan dikaitkan dengan kelompok yang dibentuk oleh kelompok Abdullah Sungkar pada akhir tahun 1970-an yaitu "Jamaah Mujahidin Ansharullah". Keberadaan Jamaah Islamiyah itu sendiri dalam kasus tersebut telah dikaitkan dengan kelompok Abdullah Sungkar dan Abdullah Ba'asyir yang memperjuangkan pembentukan Negara Islam Indonesia (NII).Jamaah Islamiyah masih merupakan satu komponen dari jaringan NII. ${ }^{11} \mathrm{Abu}$ Bakar Ba'asyir sendiri membantah keterlibatannya dengan Jamaah Islamiyah dan menyatakan tidak tahu menahu tentang Jamaah Islamiyah.Meskipun Jamaah Islamiyah dituduh melakukan pemboman di hotel JW Mariot, Jakarta, keterkaitan Abu Bakar Ba'asyir dengan aksi itu dinyatakan tidak terbukti oleh pengadilan. ${ }^{12}$

Untuk memelusuri lebih jauh idiologi dan struktur Jamaah Islamiyah bentukan Abdullah Sungkar setelah bubarnya hubungan dengan NII, maka sebuah buki panduan organisasi yang sempat diterbitkan dan banyak dikenal sebagai PUPJI (Pedoman Umum Perjuangan Jamaah Islamiyah), sedikit banyak memberikan gambaran yang cukup jelas. Arti penting buku PUPJI ini antara lain merupakan pegangan utama bagi para pengurus Jamaah Islamiyah dalam menjalankan dan memahami organisasi. ${ }^{13}$

Jamaah Islamiyah berada dibalik serangan bom bunuh diri Bali. JI, sejak lama dituduh berada di balik serangkaian serangan bom di Indonesia.Serangan paling mematikan adalah ledakan bom yang hampir bersamaan di dua klub malam di Bali tanggal 12 Oktober 2002, 202 orang tewas dan 88 diantaranya adalah warga Australia.JI, atau sel-sel yang berafiliasi dengan kelompok ini, juga dituduh terlibat dalam sejumlah serangan dengan sasaran Kristed di Indonesia Timur, serangan bom bunuh diri di depan gedung kedutaan besar Australia bulan September 2004 dan serangan serupa ke hotel JW Marriott Jakarta bulan Agustus 2003.Sebelum serangan tahun 2009 ke hotel Ritz Carlton, Jakarta, JI diperkirakan dalam keadaan berantakan setelah sejumlah pemimpin mereka ditangkap atau tewas.Namun para pengamat keamanan dan pejabat Indonesia memperingatkan

\footnotetext{
${ }^{10}$ Network Jamaah Islamiyah in South-east Asia and current

${ }^{11} \mathrm{M}$ Zaki Mubarak, Genealogi Islam Radikal di Indonesia Gerakan, Pemikiran dan Prospek Demokras, (Jakarta: LP3ES, 2007), hal. 324-325.

${ }^{12} \mathrm{http}: / / w w w . w i k i p e d i a . c o m$.

${ }^{13}$ M Zaki Mubarak, Genealogi Islam .....hal. 329.
} 
bahwa keberadaan jaringan di propinsi Aceh bisa menjadi indikasi kebangkitan militansi. ${ }^{14}$

Praktik "berjihad" dengan melakukan serentetan pengeboman, termasuk bom bunuh diri, diberbagai lokasi di tanah Air yang berlangsung sejak tahun 2000 sampai 2005, misalnya, telah memicu reaksi baik yang sangat keras dari beberapa anggota dan mantan anggota Jamaah Islamiyah sendiri. Umumnya keberatan atas aksi-aksi tersebut berdasarkan alasan bahwa para pelaku telah melakukan kesalahan fatal dengan banyak membunuh warga sipil yang tidak bersalah.Selain itu, konsepsi jihad melawan musuh musuh Islam yang kerap dilontarkan sebagai pembenar teror berdarah tersebut juga mendapatkan sanggahan dari banyak pihak. ${ }^{15}$

Catatan menunjukkan, setidaknya ada sekitar 317 anggota JI yang telah ditangkap dan diadili atas sejumlah kasus terorisme. Mulai kasus Bom Bali I dan II, Bom Hotel Marriott, Bom Kuningan, Bom Atrium Senen, Bom Malam Natal tahun 2000, Bom di Kediaman Dubes Filipina serta kasus terorisme di Poso. Penangkapan pemimpin darurat JI, Zarkasih dan pemimpin sayap militer Abu Dujana, tak pelak merupakan salah satu puncak keberhasilan polisi. Diyakini, penangkapan kedua petinggi itu telah memporak- porandakan organisasi Jamaah Islamiyah. Nyatanya, serangan bom teror juga sudah menurun sangat jauh. Tetapi Kepada Deutsche Welle dari dalam selnya, Abu Dujana meyakinkan, bahwa masih banyak kader JI yang siap melanjutkan aksi-aksi maut jaringan teror Asia Tenggara ini. ${ }^{16}$

Sebagai bentuk antitesa dari Jamaah Islamiyah, NU mengahdirkan sebuah betuk gerakan Islam moderat. Persepsi Islam moderat di wacanakan dalam salah satu ayat QS. al-Baqarah [2]: 143 yang mengatakan: "Dan demikianlah (pula) Kami telah menjadikan kamu suatu umat pertengahan (umat yang unggul), agar kamu menjadi saksi bagi manusia. Utusan menjadi saksi bagi kamu”. Cak Nur (Nurcholish Madjid) memberikan definisi terkait dengan terma "ummatan wasathan" yaitu kelompok masyarakat yang punya karakteristik moderat, dengan sikap-sikap moderasi, sebagai ciri utamanya dalam menghadapi berbagai konflik, dan konfrontasi yang disebabkan karena perbedaan. Moderasi meniscayakan sebuah keseimbangan (tawazun) dalam bersikap yang tidak memihak siapapun.

Dalam pandangan Gus Mis (sapaan akrab Zuhairi Misrawi-seorang intelektual muda NU) moderasi memiliki pijakan yang sangat mendasar. Pertama, sikap moderat adalah sikap yang paling adil dalam menerjemahkan teks suci dalam kehidupan sehari-hari disatu sisi dan memahami realitas kekinian disisi

\footnotetext{
${ }^{14}$ Network Jamaah Islamiyah in South-east Asia and current

${ }^{15}$ Ba'asyir menyatakan bahwa tindakan bom bunuh diri yang berlangsung beberaa tahun terakhir tergolong sebagai al Istisyhad (mencari mati syahid), dan pelakunya dinyatakan sebbagai mujaddid. Namun Ba'asyir menyebut aksi-aksi tersebut sebagai "salah tempat" sebab dilakukan diwilayah aman (Indonesia), dan bukan diwilayah konflik seperti diamalkan para sahabat Nabi. Padahal praktik al istisyhad menurut Syafi'i hanya dapat dilakukan diwilayah perang atau konflik. Lihat, Abu Bakar Ba'asyir,Catatan dari Penjara: Untuk Mengamalkan dan menegakkan Dinul Islam (Depok: Mushaf, 2006), hal. 282-283. Lihat: M Zaki Mubarak, Genealogi Islam Radikal di Indonesia Gerakan, Pemikiran dan Prospek Demokras, (Jakarta: LP3ES, 2007), hal. 331-332.

${ }^{16}$ http://www.dw.com/id/strategi-baru-jemaah-islamiyah-di-indonesia/a-3207951
} 
lain. Kedua, moderasi meniscayakan perdamaian, menolak kekerasan, menjunjung demokrasi, HAM, dan hak-hak perempuan.

Dari urgensi Islam moderat tersebut, dibawah ini adalah beberapa upaya untuk dapat memperkokoh visi moderasi yang harus dikembangkan oleh generasi muda muslim Nahdlatul Ulama (NU) maupun generasi-generasi muda Indonesia lainnya. Pertama, Membangun pemikiran Islam yang berbasis kultur Indonesia yang dipadukandengan modernisasi. Sebagaimana tertuang dalam salah satu kaidah "al-Muhafadhotu 'ala qadimi al-Shalih wa al-Akhdzu bi al-Jadid alAshlah" (menjaga tradisi-tradisi lama sembari menyesuaikan dengan tradisitradisi modern yang lebih baik). Kedua, Mengupayakan gerakan keIslaman berbasis ekonomi, yakni dengan membangun sebuah tatanan aktivitas perekonomian yang memberikan. Ketiga, Menciptakan ruang dialog inklusif (terbuka) baik dengan kelompok-kelompok atau aliran-aliran internal dalam Islam maupun dengan berbagai kalangan pemuka agama non-Islam.

Untuk mewujudkan itu, Beberapa poin pembenahan yang perlu diperhatikan NU adalah, pertama: profesionalisasi organisasi secara internal. Di tahun-tahun terakhir NU mulai giat mengadakan kegiatan pelatihan kader di seluruh bidang dan tingkat. Kegiatan ini mesti terus ditingkatkan, karena masih belum menyentuh semua wilayah secara menyeluruh. Cultural shock dari manajemen tradisional ke profesional dan disiplin adalah hal yang mesti diantisipasi. Kedua, peningkatan penguasaan keilmuan guna menjaga bangunan pemahaman Islam moderat dengan baik. Ketiga, peningkatan keterampilan komunikasi. Keempat, penguatan jejaring Muslim moderat global melalui pengembangan Pengurus Cabang Istimewa di luar negeri.

Gagasan NU didirikan tak terlepas dari keinginan para pioneer-nya untuk tidak alergi terhadap percepatan kemajuan dan perkembangan ilmu pengetahuan, sehingga setiap perubahan sosial harus disesuaikan tanpa harus dibenturkan dengan adat, nilai keagamaan ataupun tradisi yang telah lebih dahulu hadir ditengah-tengah masyarakat.

Disinilah NU lahir sebagai gerakan sosial mempertahankan tradisi yang sudah mapan dan baik dalam masyarakat seraya memperkuat nilai-nilai keIslaman yang telah lama tumbuh tanpa harus berbenturan dengan perkembangan zaman. Adagium klasik selalu dipakai ormas keagamaan ini sejak awal didirikannya, yaitu "al-muhafadlotu 'ala qodiim al-sholih wa al-akhdzu bi al-jadid al-ashlah" (menjaga sesuatu yang baik di masa lampau dan mengambil yang baru yang lebih baik). Kaidah ini berimplikasi terhadap cara pandang NU soal nilai-nilai sosial keagamaan Islam secara otentik dan substantif: senantiasa memegang teguh kemurnian ajaran Islam yang diajarkan para ulama yang memiliki matarantai pengetahuan (sanad) keagamaan secara sah serta mengedepankan wajah Islam yang substantif berupa penguatan nilai-nilai Islami tanpa harus menonjolkan "sisi luar" Islam melalui simbol-simbol keagamaan.

Orientasi keagamaan NU yang selalu mengedepankan prinsip "jalan tengah" dalam konteks pemikiran keagamaan, sosial maupun politik cukup membuat organisasi ini dipandang oleh banyak kalangan sebagai pembawa panji Islam moderat yang senantiasa meneguhkan prinsip rahmatan lil alamin. NU sejauh ini dinilai memiliki kemampuan untuk memperlihatkan wajah Islam moderat, 
akomodatif, toleran yang sesuai dengan cita-cita sebagai Islam rahmatan lil 'alamin.

Wujud dari Islam Rahmatan Lil 'Alamin diterjemahkan Islam Nusantara. Sebuah wajah Islam sesungguhnya yang memiliki nilai-nilai humanisme, pluralisme dan cenderung akomodatif terhadap segala perbedaan dalam ranah sosial-politik. Islam Nusantara sebenarnya hendak menunjukkan bahwa Ke-NUan, KeIslaman dan Kebhinekaan yang telah mengkristal dalam sejarah bangunan Nusantara merupakan warisan keagamaan yang dibawa oleh para ulama yang selama ini menjadi panutan warga Nahdliyyin.

Slogan Islam Nusantara yang digaungkan NU secara tidak langsung merupakan kritik terhadap kelompok tertentu yang masih mempermasalahkan keragaman dan cenderung mengedepankan simbol-simbol keagamaan yang justru bertolak belakang dengan substansi ajaran Islam itu sendiri. Dengan konsep ini Islam Nusantara setidaknya menjadi pemcegah bagi rusakanya sebuah tatanan. Inilah yang selalu dipegang oleh NU melalui adagium fiqh-nya yang terkenal, "dar'u al-mafaasid muqaddamun 'ala jalbi al-mashalih" (mencegah kerusakan harus didahulukan daripada membangun kemaslahatan).

\section{Jama'ah Islamiyah dan Gerakan Radikal}

SALAH satu kajian yang amat menarik memasuki abad ke-21 adalah bagaimana menjelaskan aksi radikalisme dan terorisme di Indonesia. Selain gerakan kekerasan yang tampak, ada kesalahpamahan umat Muslim sendiri yang cenderung literalistik dalam memahami teks-teks keagamaan (al-Qur'an dan alHadits) telah menambah faktor menguatnya isu terorisme. ${ }^{17}$ Hal ini diperparah lagi dengan sikap dan ekspresi keagamaan "sebagian" umat Muslim yang cenderung eksklusif dan seringkali menjustifikasi pemahaman keIslaman-nyalah yang dianggap paling benar. Anasir-anasir itulah yang telah menebar, tidak hanya pertarungan antar ideologi keagamaan tetapi juga membuka secara lebar wacana terorisme di belahan dunia. Terutama dalam konteks global, pasca tumbangnya WTC di USA pada tahun 2001, terorisme yang mendapat dukungan dari gerakan radikalisme dan fundamentalisme agama kerap menjadi obyek dari tuduhan pelaku pengeboman. Tentu saja fenomena tersebut di satu sisi semakin memperkuat kecurigaan Barat terhadap dunia Islam, ${ }^{18}$ di sisi lain dapat dibantah

\footnotetext{
${ }^{17}$ Kajian yang pernah dilakuklan Azyumardi Azra dan Bassam Tibi mengenai fundamentalisme Islam tampaknya sudah tidak memadai lagi untuk menjelaskan fenomena terorisme yang belakangan menggurita dan memiliki variasi gerakan. Kajian yang menekankan pada pendekatan historis tersebut bisa dibaca Azyumardi Azra, "Fenomena Fundamentalisme dalam Islam: Survey Historis dan ", Jurnal Ulumul Qur'an, Nomor 3, Vol. IV, Th. 1993, dan Bassam Tibi, The Challenge of Fundamentalism Political Islam and he New World Disorder (California: the Regent of University of California, 1998). Sebaliknya, untuk memahami fenomena terorisme dapat dibaca pada karya Dana R. Dillon, "The Shape on Anti-Terorist Coalition in Southeast Asia," Heritage Lectures, 13 Desember 2002, dan dalam konteks Indonesia, karya Rizal Sukma cukup menjadi literatur awal yang bertitelkan "Indonesia's Islam and September 11: Reactions and Prospect," dalam Andrew Tan dan Kumar Ramakrishna (ed.), The New Terorism: Anatomy, Trends, and Counter-Strategies (Singapore: Eastern University Press, 2002)

${ }^{18}$ Samuel P. Huntington, The Clash of Civilization and the Remaking of World Order (London: Touchstone Books, 1998)
} 
banyak kalangan terutama internal Islam sendiri yang mengatakan bahwa tidak semua aksi teroris itu mewakili umat Muslim. ${ }^{19}$

Aksi teror di Indonesia sepanjang dua dasawarsa ini dapat telah terjadi pada tragedi JW Marriot bombing, Bali bombing I, Kuningan bombing, Bali bombing II, dan hotel Ritz-Carlton Jakarta, dan terakhir bom Sarinah. Aksi teror ini tidak ubahnya merupakan opera dan orkestra vulgar dari sebuah proyek dehumanisasi global, total, syumul dan kaffah. Tidak jarang para pelaku teror tersebut melakukan semua itu untuk memenuhi tuntutan teologi yang mereka pahami. Islam seakan mengajarkan kepada para pengikutnya yang setia dan fanatik untuk melakukan tindakan-tindakan teror itu sebagai wujud dari keimanan. Doktrin teologi mereka bahkan mengklaim kebenaran bahwa Tuhan telah menyuruhnya untuk melakukan apa saja yang mungkin demi membela agama-Nya. ${ }^{20} \mathrm{Hal}$ inilah yang membawa kita untuk terus berujar, jika mereka melakukan itu semua dengan atas nama membela Tuhan dan mengaplikasikan pesan Sang Rasul, maka hal ini merupakan penghinaan, pengkoyakan, pencabikan dan pendistorsian terhadap nilai suci teks agama. ${ }^{21}$

\section{Fundamentalisme Islam dan Terorisme: Antara Image dan Realitas}

Kajian historis yang pernah dilakukan Murba Abu, ${ }^{22}$ menulis sepuluh faktor yang mempengaruhi tumbuhnya radikalisme di kalanga umat Muslim di Indonesia. Kesepuluh faktor tersebut diajukan dengan menyebut beberapa aktor yang terlibat. Namun karena adanya kadekatan faktor yang terkait, penulis meringkasnya menjadi lima faktor. Pertama, akibat kekecewaan politik pada persoalan "Piagam Jakarta" yang tidak berhasil dijadikan sebagai dasar negara Indonesia. Kartosuwiryo, tokoh Masyumi garis keras menumpahkan kekecewaannya dengan memproklamirkan Negara Islam Indonesia (NII) pada bulan Agustus 1948. Gerakan melebar ke di Aceh yang dipimpin Daud Beureuh dan Kahar Muzakkar di Sulawesi. ${ }^{23}$ Kedua, akibat perilaku dan tekanan politik Orde Baru.

Ketiga, kelompok yang terinspirasi dari Gerakan Revolusi Iran pada tahun 1979 dan gerakan Islam Timur Tengah. Selain inspirasi revolusi yang dipelopori

\footnotetext{
${ }^{19}$ Ian Markham dan Ibrahim Abu Rabi' (ed.), 11 September: Religious Perspective on the Causes and Consequences (Oxford: One World, t.th).

${ }^{20}$ Machasin, "Fundamentalisme dan Terorisme", dalam A. Maftuh \& A. Yani, Negara Tuhan: The Thematic Encyclopaedia (Yogyakarta: SR-Ins, 2004), hal. 791.

${ }^{21}$ Studi agama yang ditawarkan Syafa'atun El-Mirzanah, Ph.D mengenai kitab-kitab suci dalam tradisi agama bersifat korpus terbuka dan terikat dengan pendekatan polyinterpretable sangat memadai untuk menolak anggapan para pegiat fundamentalisme dan terorisme. Demikian pula karya para intelektual muslim progresif yang diedit Omid Safi cukup menarik untuk dikaji, Omid Safi (ed.), Progressive Muslims on Justice, Gender, and Pluralism (England: Oneworld Oxford, 2003)

${ }^{22}$ Murba Abu, "Memahami Terorisme di Indonesia", dalam A. Maftuh \& A. Yani, Negara

Tuhan: The Thematic Encyclopaedia (Yogyakarta: SR-Ins, 2004), hal. 734-745

${ }^{23}$ Lihat misalnya karya Holk H. Dengel, Darul Islam dan Kartosuwiryo: "Angan-Angan yang Gagal," (Jakarta: Sinar Harapan, 1995).
} 
Khomeini di Iran, kelompok ini juga mendapat inspirasi gerakannya terutama model Ikhwan al-Muslimin yang dibentuk Hasan al-Banna di Mesir. ${ }^{24}$

Keempat, kelompok dari pesantren. Kelompok ini dimunculkan sebagai akibat dari munculnya para pelaku bombing di berbagai tempat di Indonesia merupakan alumni dari beberapa pesantren yang berhaluan kanan. setidaknya ada tiga pondok pesantren yang sering disebut dalam diskursus Islam radikal di Indonesia, yaitu pesantren Ngruki di Surakarta pimpinan Abu Bakar Ba'asyir, alZaitun di Indramayu pimpinan $\mathrm{Abu}$ Toto, dan pesantren Al-Islam di Lamongan. ${ }^{25}$ Kelima, sebagai bagian dari organisasi transnasional Islam.

\section{SIMPULAN}

Pandangan tentang negara barulah akan bersifat penolakan bentuk yang ada, jika keseluruhan tradisi keilmuan yang dianut NU telah memberikan legitimasi untuk itu seperti terjadi dengan "fatwa perang jihad" yang dikeluarkan Rais Akbar NU K.H. Hasyim Asy'ari pada permulaan perang kemerdekaan, yang mendukung bentuk negara baru Republik Indonesia. Pendekatan serba fiqh atas masalah-masalah kenegaraan itulah yang membuat NU relative lebih mudah menerima ketentuan pemerintah tentang asas Pancasila dalam kehidupan berorganisasi dewasa ini. Dalam pandangan fiqh asas Pancasila adalah salah satu dan sekian buah persyaratan bagi keabsahan negara republik Indonesia; hal itu pun bukannya persyaratan keagamaan sama sekali.

Dengan meletakan kunci masalah pada pengesahan hukum fiqh, NU mampu melakukan sebuah proses penyesuaian dengan tuntutan sebuah negara modern, walaupun dalam aspek kenegaraan pandangan serba fiqh itu juga sering merupakan "hambatan" bagi pemegang pemerintahan untuk melaksankana wewenangnya.

Mekanisme "setuju untuk tidak bersetuju" (agree to disagree) itu menjamin adanya proses tolak-angsur yang sangat fleksibel di lingkungan pengambilan keputusan dalam NU, sehingga dapat terjaga keutuhan organisasi yang senantiasa dipenuhi perbedaan pendapat itu. Walaupun ada juga kelemahan mekanisme pengambilan konsesus untuk setuju (dan juga untuk tidak setuju)seperti itu.

Fenomena radikalisme Islam sebagai sebuah ekspresi dari gerakan politik sebagian umat Muslim yang berujung pada upaya ideologisasi Islam secara formal pada dasarnya tidak dipisahkan dari faktor doktrin Islam, sikap politik dan gerakan politik yang dilancarkan. James P. Piscatori menegaskan bahwa sebagai sebuah sistem komunal, para pemeluk Islam menghadirkan ekspresi ke-Islaman yang varian. Banyak faktor yang mempengaruhi ekspresi politik umat Islam ketika berhadapan dengan realitas sosial dan politik yang berkembang.

\footnotetext{
${ }^{24}$ Ali Said Damanik, Fenomena Partai Keadilan: Transformasi 20 Tahun Gerakan Tarbiyah di Indonesia (Bandung: Teraju, 2003).

${ }^{25}$ E.S. Soepriyadi, Ngruki dan Jaringan Terorisme: Melacak Jejak Abu Bakar Ba'asyir dan Jaringannya dari Ngruki sampai Bom Bali (Jakarta: Al-Mawardi Prima, 2003); dan ICG Asia, Jamaah Islamiyyah in South-East Asia: Damaged but Still Dangerous, No.63, 26 Agustus 2003
} 
Tawaran sekaligus menjadi solusi terhadap upaya meminimalisir gerakan terorisme dengan cara menolak kekerasan dan sebaliknya menjadi penting meruntuhkan landasan epistimelogi mereka dengan mengajukan empat hal yang menjadi pertimbangan dalam kaca mata akademis, yaitu; Pertama, jaringan radikalisme internasional yang bernama al-Qaedah dan al-Jama'ah al-Islamiyyah merupakan "buah" dari "pohon rindang" pemahaman skripturalistik verbalis terhadap teks-teks keagamaan yang dipaksakan untuk melegitimasi "violence action" dengan "menyeru jihad menebar teror (syann al-gharah) atas nama "Tuhan" dan atas nama "agenda Rasul". Termasuk di dalamnya jaringan terorisme di Indonesia di mana aktor-aktornya adalah meruapakan alumni perang Afghan dan jaringan yang telah dipupuk sejak tahun 1970-an melalui Al-Jamaah AlIslamiyah.

Kedua, pemahaman bahasa agama secara literalistik serta verbalis menjadi problematis ketika dihadapkan pada ranah sosial dan budaya yang heterogen. Ketiga, pemahaman keagamaan secara literalis-skripturalistik sering terjebak dalam ruang ideologis yang bercirikan subyektif, normatif dan tertutup.

Keempat, dalam wilayah sosial-politik, pemahaman literalis terhadap teksteks al-Qur'an dan sunnah berakibat kepada aspek simplikasi terhadap Islam yang berujung kepada fundamentalisme.

\section{DAFTAR PUSTAKA}

Awwas, I.S. Pengadilan Teroris: Klarifikasi dan Dusta yang Terungkap di Persidangan. Yogyakarta: Wihdah Press. 2004

Aziz, A.. Imam Samudra: Aku Melawan Teroris. Solo: Jazeera, 2004

Abdul Baqi Surur, Dawlah al-Qur`an, Kairo: Dar al-Nahdhah, 1972

Ahmad Syafi'i Ma'arif, Islam as the Basis of State: A Study of the Islamic Political Ideas as Reflekcted in the Constituent Assembly Debates in Indonesia, disertasi doktor, University of Chicago, 1983

Albert Hourani, Arabic Thought in the Liberal Age 1798-1939, Cambridge: Cambrige University Press.

Ali Abdurraziq, al-Islam wa Ushul al-Hukm: Bahts fiy al-Khilafah wa alHukumah fiy al-Islam, Beirut: 1966.

Azyumardi Azra, Pergolakan Politik Islam: Dari Fundamentalisme, Modernisme, Hingga Post-Modernisme, Jakarta: Paramadina, 1996,

Bahtiar Effendi, Islam dan Negara: Transformasi Pemikiran dan Praktik Politik di Indonesia, Jakarta: Paramadina, 1998

Ba'asyir, A. B.. Sistem Kaderisasi Mujahidin dalam Mewujudkan Masyarakat Islam. Dalam I.S. Awwas (ed.), Risalah Kongres Mujahidin I dan Penegakkan Syari'ah Islam. Yogyakarta: Wihdah Press 2001

Eisinger Theories of Political Protest and Social Movement: A Multidisciplinary Introduction, Critique, and Synthesis, 1971 
Fachri Ali \& Bahtiar Effendy, Merambah Jalan Baru Islam (Mizan: Bandung, 1986

Fazlurrahman, Islam and Modernity: Transformation of an Intellectual Tradition, Chicago: University of Chicago Press, 1982.

---------, The Islamic Concept of State, dalam John J. Donohue dan L. Esposito (ed.), Islam in Transition: Muslim Perspective, (New York: Oxford University Press, 1982.

Fealy Greg, Ijtihad Politik Ulama, Sejarah NU 1952-1967, LKiS, Yogyakarta: 2003

Hasan Turabi, al-Harakah al-Islamiyah fiy Sudan: al-Tathawwur wa al-Kasb wa al-Manhaj, Lahore: Iman, 1410/1990

, al-Shahwah al-Islamiyah wa al-Dawlah al-Quthriyyah fiy al-Wathan al'Arabiy, dalam Sa'd al-Din Ibrahim (ed.), al-Shahwah al-Islamiyah wa Humum al-Wathan al-'Arabiy, Amman: Muntadza al-Fikr al-'Arabiy, 1988.

---------, Islam, Democracy, the State, and the West", Middle East Policy 1, No. 3, 1992.

, "The Islamic State" dalam dalam Voices of Resurgent Islam, disunting oleh John L. Esposito, New York: Oxford University Press, 1983

Husain Haykal, Mudzakkirat fiy al-Siyasah al-Mishriyah, Kairo: Dar al-Ma'arif, 1990.

, al-Hukumah al-Islamiyah, Kairo: Dar al-Ma'arif, 1993

---------, Mudzakkirat fiy al-Siyasah al-Mishriyah, Kairo: Dar al-Ma'arif, 1990.

John L. Esposito, Islam dan Politik (Jakarta: Bulan Bintang, 1990)

KH Imron Hamzah \& Choirul Anam (peny.), Gus Dur Diadili Kiai-Kiai, Surabaya: Jawa Pos, 1989.

Leonard Binder, Islamic Liberalism, Chicago and London: 1988.

Mahmudi Ahmad, Peran NU Dalam Pembentukan Ideologi Negara RI, Fakultas Syariah dan Hukum, UIN Kalijogo, Yogyakarta, 2014

Mc Adam, Recruitment to High-Risk Activism: The Case of Freedom Summer. American Journal of Sociology, 1986,

McAdam,. "Conceptual Origins, Current Problems, Future Directions." In Comparative Perspectives on Social Movements, edited by McAdam, McCarthy, and Zald. 1996

M. Syafi'i Anwar, Pemikiran dan Aksi Islam Indonesia: Sebuah Kajian Politik tentang Cendekiawan Muslim Orde Baru, Jakarta: Paramadina, 1995

Moeslim Abdurrahman, Islam Transformatif, Jakarta: Pustaka Firdaus, 1995

--------, Semarak Islam, Semarak Demokrasi ?, Jakarta: Pustaka Firdaus, 1996.

Muhammad Yusuf Musa, Nidham al-Hukm fiy al-Islam, Kairo: dar al-Kitab al'Arabiy, 1963.

Munawir Sjadzali, Islam dan Tata Negara, Jakarta: UI-Press, 1990

Mundlir Abdul, Septina Alrianingrum, , Peran Politik Nu Tahun 1952-1955, Avatara ,Jakarta2014

Qamaruddin Khan, Tentang Teori Politik Islam, Bandung: Pustaka, 1998

---------, Pemikiran Politik Ibnu Taymiyah, (Bandung: Pustaka, 1995 
R. William Lidlle, Politics and Culture in Indonesia, Ann Arbor: Center for Political Studies Institute for Social Reasen the Indonesia, 1998.

Sayyid Qutb, al-'Adalah al-Ijtima'iyah fiy al-Islam, Beirut: Dar al-Kitab al'Arabiy, 1967.

Syaikhu,Ach. Pergulatan Organisasi Islam dalam Membendung Gerakan Ideologi Islam Transnasional, Jurnal Falasifa: Jakarta , 2012

Surat Kabar,Majalah dan Jurnal

Majalah Tempo terbitan bulan Januari dan Februari tahun 2001 dan Oktober 2002

Majalah Tempo terbitan bulan Agustus 2003 dan September 2004 dan Oktober 2005

Koran Harian Umum Kompas, edisi 22, 23, 26 dan 28 Agustus 2009 